\title{
Performance of Sheep and Goats Fed Arctostaphylos canescens With and Without Polyethylene Glycol Supplementation
}

\author{
Nelmy Narvaez, ${ }^{1}$ Arieh Brosh, ${ }^{2}$ Miguel Mellado, ${ }^{3}$ and Wolfgang Pittroff ${ }^{4}$
}

Authors are ${ }^{1} \mathrm{PhD}$ in Ecology and ${ }^{4}$ Assistant Professor, Department of Animal Science, University of California, Davis, CA 95616, USA; ${ }^{2}$ Senior Scientist, Newe Ya'ar Research Center, PO Box 1021, Ramat Yishay 30095, Israel; and ${ }^{3}$ Professor, Department of Nutrition and Foods, Universidad Autonoma Agraria Antonio Narro, Saltillo, Coach. 25315, Mexico.

\begin{abstract}
Arctostaphylos canescens Eastw. is considered an important element in the chaparral fire matrix and an invasive plant in coniferous forest plantations in California. Previous studies reported that dry matter intake of Arctostaphylos was low, presumably because of its low nutritional quality and high condensed tannin (CT) content. We hypothesized that intake and digestibility of Arctostaphylos could be increased by the provision of a tannin-complexing agent polyethylene glycol (PEG). This study determined the effects of PEG (MW 4000) supplementation on intake (I) and digestibility (D) of Arctostaphylos in goats and sheep. Polyethylene glycol was added to drinking water at four levels $(0.3 \%, 0.15 \%, 0.05 \%$, and $0 \%)$ of body weight $(\mathrm{BW})$. Alfalfa pellets were used as diet supplement at $1.5 \%$ of BW. Nutritional quality of Arctostaphylos was low as compared with alfalfa pellets. Arctostaphylos crude protein (CP) levels were low $(4.5 \%$ vs. $17.9 \%)$ and CT concentration was high $(23.1 \%$ vs. $0 \%$ ), whereas estimates of in vitro organic matter digestibility (OMD, 36.6\%) and metabolizable energy $\left(5.1 \mathrm{MJ} \cdot \mathrm{kg}^{-1} \mathrm{dry}\right.$ matter $[\mathrm{DM}])$ in Arctostaphylos were almost half of those found for alfalfa pellets $\left(70.3 \%\right.$ and $\left.9.5 \mathrm{MJ} \cdot \mathrm{kg}^{-1} \mathrm{DM}\right)$. A curvilinear increase $(P<0.05)$ in nutrient intake (per $\mathrm{g} \cdot \mathrm{d}^{-1}$ and per $\mathrm{kg} \mathrm{BW}{ }^{0.75}$ ) was observed in goats and sheep as PEG levels increased, although a linear increase $(P<0.001)$ was observed in CP intake $\left(\mathrm{g} \cdot \mathrm{d}^{-1}\right)$ of Arctostaphylos by goats. Addition of PEG curvilinearly increased $(P<0.05)$ digestibility of $\mathrm{DM}, \mathrm{CP}$, and neutral and acid detergent fiber, but quadratically increased $(P<0.05)$ that of OM in goats and sheep. Incorporation of PEG in drinking water at the level of $0.15 \% \mathrm{BW}$ in sheep and goats was effective to maximize inactivation of CT in Arctostaphylos. However, the success in adopting this practice as a useful tool in vegetation management programs will depend on the cost-benefit ratio.
\end{abstract}

\section{Resumen}

Arctostaphylos canescens Eastw es muy importante en el patrón del fuego del chaparral y se considera como una invasora en plantaciones forestales. Previos estudios han reportado que el consumo de materia seca (CMS) de Arctostaphylos ha sido bajo, posiblemente debido a su baja calidad nutritiva y su alto contenido de taninos condensados (TC). Presentamos la hipótesis que el consumo y digestibilidad (D) de la materia seca de Arctostaphylos se puede aumentar con el uso de polietilén glicol (PEG), el cual forma complejos estables con taninos. Este estudio determinó el efecto de suplementación de PEG (PM 4000) sobre el CMS y DMS de Arctostaphylos en cabras y ovejas. El PEG se agregó al agua de consumo a cuatro diferentes niveles $(0.3 \%, 0.15 \%$, $0.05 \%$, y $0 \%$ ) del peso vivo (PV). Los animales se suplementaron con concentrado de alfalfa al $1.5 \%$ PV. La calidad nutritiva de Arctostaphylos fue baja comparada a la de alfalfa. Los niveles de proteína cruda (PC) fueron bajos $(4.5 \%$ vs. $17.9 \%)$ y la concentración de TC fue alta $(23.1 \%$ vs. $0 \%)$, mientras que la digestibilidad de la materia orgánica (DMO, 36.6\%) y la energía metabolizable (EM, $\left.5.1 \mathrm{MJ} \cdot \mathrm{kg}^{-1} \mathrm{MS}\right)$ estimadas in vitro fueron casi la mitad de la estimada en alfalfa $\left(70.3 \%\right.$ y $9.5 \mathrm{MJ} \cdot \mathrm{kg}^{-1}$ MS). Un incremento cuadrático y lineal $(P<0.05)$ en el consumo de nutrientes $\left(e n g \cdot \mathrm{d}^{-1}\right.$ y por $\mathrm{kg} \mathrm{PV}^{0.75}$ ) se encontró en cabras y ovejas con el incremento de los niveles de PEG, aunque un incremento lineal $(P<0.001)$ se detectó en $\mathrm{CPC}\left(\mathrm{g} \cdot \mathrm{d}^{-1}\right) \mathrm{de}$ Arctostaphylos en cabras. La adición de PEG incrementó cuadrática y linealmente $(P<0.05)$ la digestibilidad de la MS, de la PC, y de la fibra detergente neutra y ácida, pero incrementó cuadráticamente $(P<0.05)$ la de la MO en cabras y ovejas. La incorporación de PEG en el agua de consumo al nivel de $0.15 \%$ de PV en ovejas y cabras fue efectiva para inactivar los TC reactivos en Arctostaphylos. Sin embargo, el éxito de su adopción como una herramienta útil en programas de manejo de vegetación dependerá de la relación costo:beneficio.

Key Words: chaparral, fuel management, manzanita, shrub management, tannins

\footnotetext{
This study was supported by the California Agricultural Experiment Station, University of California.

Correspondence: Nelmy Narvaez, Agriculture and Agri-Food Canada, Lethbridge Research Centre, PO Box 3000, Lethbridge, Alberta T1J 4B1, Canada. Email: Nelmy.Narvaez@agr. gc.ca

Manuscript received 21 April 2009; manuscript accepted 13 September 2010.
}

\section{INTRODUCTION}

Manzanita (Arctostaphylos spp.) is a significant component of the chaparral fire matrix responsible for increasingly frequent catastrophic wildfires at the wildland-urban interface of California. Sclerophyllous leaves of Arctostaphylos spp. con- 
tain many substances that ignite and burn easily, such as oils, waxes, resins, fats, and alcohols (Rundel and Parsons 1980; Rundel et al. 1980). Further, encroachment of these species is a serious problem in forest plantations. Control of fuel load and brush encroachment in forest plantations is mostly achieved by prescribed fire, herbicides, and mechanical clearing (Hart 2001). However, risk, cost, and air and water quality considerations increasingly restrict the application of these tools for vegetation management (Hart 2001). Interest in using small ruminants as an alternative tool to reduce fuel load and to suppress undesirable vegetation in forest plantations has expanded rapidly in California. Prescribed herbivory with domestic livestock has the potential to become an ecologically and economically sustainable tool for vegetation management. However, this tool presents many unresolved technical problems. Various manzanita species have low nutrient content, high condensed tannin (CT) concentration (Sidahmed et al. 1981a, 1981b; Narvaez et al. 2010), and low intake and palatability (Sampson and Jespersen 1963; Brennecke and Pittroff 2003), which limit its potential nutritive value as feed for ruminants. For instance, concentration of CT in leaves of three different Arctostaphylos species are as high as $280 \mathrm{~g} \cdot \mathrm{kg}^{-1}$ dry matter (DM; Narvaez et al. 2010). Tannins form insoluble complexes with proteins in the diet (Van Sumere et al. 1975), rendering them unavailable for rumen microorganisms and the host animal. Consequently, tannins decrease palatability, DM and protein digestibility, and feed intake and cause enzyme inhibition (Nastis and Malechek 1988; Kumar and Vaithiyanathan 1990; Barry and McNabb 1999).

Several methods have been used to deactivate tannins and other secondary compounds in temperate and tropical forages to improve the nutritive value of these plants (Makkar 2003). The most common is the deactivation of tannins to enhance the feeding value of tannin-rich diets by using polyethylene glycol (PEG), which is an inert molecule that forms stable complexes with tannins, thus preventing the binding of tannins to proteins (Badran and Jones 1965). Several studies reported that inactivation of tannins through PEG increased the availability of nutrients and decreased microbial inhibition, leading to increased degradability of nutrients and better animal performance (Silanikove et al. 1997; Ben Salem et al. 2000; Decandia et al. 2000).

Little is known about the true feeding value of Arctostaph$y$ los, and although several techniques to deactivate tannins have been tested on tanniniferous feeds, there are no data on the use of PEG to deactivate CT in Arctostaphylos fed to sheep and goats. This study was conducted to determine the nutritional quality of Arctostaphylos and effects of PEG supplementation on intake and digestibility in vivo in sheep and goats fed hoary manzanita (Arctostaphylos canescens).

\section{MATERIALS AND METHODS}

\section{Study Area}

The feeding experiment was conducted in April-May 2001 at the Hopland Research and Extension Center (HREC), located in Mendocino County in the North Coast of California at lat $39^{\circ} 00^{\prime} \mathrm{N}$ and long $123^{\circ} 4^{\prime} \mathrm{W}$ with an elevation from $170 \mathrm{~m}$ to $1000 \mathrm{~m}$ above sea level. The climate is Mediterranean with hot, dry summers and cool, moist winters. Annual precipitation at HREC averages $940 \mathrm{~mm}$ at $250 \mathrm{~m}$ and $1143 \mathrm{~mm}$ at $1000 \mathrm{~m}$, but it varies widely from year to year. Four major vegetation types (grass, woodland-grass, dense woodland, and chaparral) are found at HREC, including more than 800 plant species.

\section{Plant Material}

Fresh evergreen branches (leaves and stems) were handharvested every morning using pruning shears in April-May 2001 from a homogenous stand (in terms of species and age) of Arctostaphylos at the HREC. Only the terminal $20 \mathrm{~cm}$ of each twig with their associated leaves and buds were used for browse.

\section{Animal Management}

Animal care and use was reviewed and approved by the Animal Care and Use Administrative Advisory Committee of the University of California at Davis. The experiments were conducted with four wether Kiko goats $(32 \pm 3.0 \mathrm{~kg})$ and four wether Targhee sheep $(55 \pm 3.0 \mathrm{~kg})$. Animals were housed in individual metabolism crates and fed twice per day at 0700 and at 1800 hours. Prior to the study all animals were allowed to graze for $2 \mathrm{wk}$ in Hopland natural habitat, where they were exposed to Arctostaphylos naturally. All animals were treated with $0.2 \mathrm{mg}<\mathrm{kg}^{-1}$ body weight (BW) of Ivomec (Merck and Company, Rahway, NJ) for elimination of internal and external parasites before the start of the experiment. Experimental treatments consisted of polyethylene glycol supplementation (PEG, mol wt 4000) at four different levels of body weight $(0.3 \%, 0.15 \%, 0.05 \%$, and $0 \%)$ in the drinking water. Individual PEG solutions were prepared according to animal BW and offered every morning (0700 hours) to each animal. Once the animals have consumed the PEG solution, fresh water was provided ad libitum. Addition of PEG in drinking water was chosen because this method is practical under extensive land use of rangelands and has been recommended as convenient for small ruminants browsing tanniniferous species in the field or fed indoors (Ben Salem et al. 1999). Because of the low nutritive value of Arctostaphylos (Sidahmed et al. 1981b; Narvaez et al. 2010) and possible detrimental effects of high tannins (Narvaez et al. 2010), the animals were supplemented with alfalfa pellets at $1.5 \%$ of their body weight (as fed) in one meal. The amount of alfalfa supplemented remained constant throughout the experimental periods, so that increases in DM intake with PEG reflected increased intake of Arctostaphylos. The highest PEG supplementation level was the initial treatment; subsequently, PEG supplementation was reduced until it reached $0 \%$ in the last period. This design minimized carry-over effects from the antiquality compounds found in Arctostaphylos and allowed to test the PEG levels on digestibility and intake without confounding effects of time. Each experimental period (PEG level) lasted for $14 \mathrm{~d}$ ( $7 \mathrm{~d}$ for adjustment and $7 \mathrm{~d}$ for sample collection), with the exception of the first period $(0.3 \%$ PEG), which lasted for $16 \mathrm{~d}$ ( $9 \mathrm{~d}$ for adjustment and $7 \mathrm{~d}$ for sample collection). Longer adaptation for the first period was implemented to account for the maximum qualitative change in diet (i.e., full effects of the naturally occurring tannins as the animals were grazing Arctostaphylos prior to the highest level of inactivation with 
PEG), compared with gradually increasing tannin activity between $0.3 \%$ PEG and subsequent periods. All offered concentrate was consumed by all goats and sheep.

\section{Measurements and Calculations}

Feed intake and in vivo diet digestibility were determined by total fecal collection during the four periods. Daily samples from Arctostaphylos offered and refused and fecal samples for each animal were collected, weighed, and taken for dry matter determination and further chemical analyses. Samples of feed offered, refusals, and feces were dried in a forced-air oven $\left(50^{\circ} \mathrm{C}\right.$ for $\left.48 \mathrm{~h}\right)$, ground to pass through a $1-\mathrm{mm}$ screen in a Wiley mill (Arthur A. Thomas, Philadelphia, PA), and then stored in plastic containers until analysis. Animals were weighed at the beginning and the end of each experimental period.

Digestible energy (DE) concentration for each treatment was calculated from organic matter $(\mathrm{OM})$ content and $\mathrm{OM}$ digestibility $(\mathrm{OMD})$ on a basis of $18.66 \mathrm{MJ} \cdot \mathrm{kg}^{-1}$ of digested OM (National Research Council [NRC] 1989). The metabolizable energy (ME) concentrations for each treatment were calculated from the DE concentrations using the NRC (1989) equation:

$$
\mathrm{ME}\left(\mathrm{MJ} \cdot \mathrm{kg}^{-1} \mathrm{DM}\right)=0.82 \times \mathrm{DE} .
$$

\section{Chemical Analyses}

Ground samples of feed offered, refusals, and fecal samples were analyzed for DM, ash, and crude protein (CP) according to Association of Official Analytical Chemists (1990). Neutral detergent fiber (NDF) and acid detergent fiber (ADF) were determined according to Van Soest et al. (1991) and expressed with residual ash. Alpha amylase, but not sodium sulphite, was added to the solution for the NDF determination. CT were determined by the vanillin- $\mathrm{HCl}$ method (Broadhurst and Jones 1978), using (+)-catechin (Sigma Chemical Co, St. Louis, MO) as standard. Results were expressed as g equivalent catechin $\cdot 100 \mathrm{~g}^{-1}$ DM. Digestibility of OM and ME values from feed offered were calculated from the 24-h gas production using the in vitro technique described by Menke and Steingass (1988):

$$
\begin{aligned}
\operatorname{IVOMD}\left(\mathrm{g} \cdot 100 \mathrm{~g}^{-1} \mathrm{DM}\right)= & 14.88+0.889 \times \mathrm{Gp} \\
& +0.045 \times \mathrm{CP}+0.0651 \times \mathrm{XA}, \\
\operatorname{ME}\left(\mathrm{MJ} \cdot \mathrm{kg}^{-1} \mathrm{DM}\right)= & 2.2+0.136 \times \mathrm{Gp}+0.057 \times \mathrm{CP},
\end{aligned}
$$

where IVOMD is the organic matter digestibility, ME is metabolizable energy, CP is crude protein $\left(\mathrm{g} \cdot \mathrm{kg}^{-1} \mathrm{DM}\right), \mathrm{XA}$ is ash $\left(\mathrm{g} \cdot \mathrm{kg}^{-1} \mathrm{DM}\right)$, and $\mathrm{Gp}$ is the gas production in $\mathrm{mL}$ from 200-mg dry sample after $24 \mathrm{~h}$ of incubation. In this technique, the gas produced in anaerobic fermentation of substrate is used to predict the nutritive value. Bovine rumen fluid was used for the in vitro fermentation. The gas production technique was used because it is considered more efficient than other in vitro techniques in determining the nutritive value of feeds containing tannins (Getachew et al. 2002). In addition, it was found that gas production is well correlated with in vivo and in vitro digestibility (Khazaal et al. 1993) and can be used to accurately predict the ME content of a wide variety of feeds (Getachew et al. 2005).
Table 1. Chemical composition (\% dry matter [DM]), estimated in vitro organic matter digestibility (\%), and energy concentration (MJ $\left.\cdot \mathrm{kg}^{-1} \mathrm{DM}\right)$ of Arctostaphylos canescens and alfalfa pellets offered to the animals. ${ }^{1}$

\begin{tabular}{lcc}
\hline \multicolumn{1}{c}{ Parameter } & Arctostaphylos canescens & Alfalfa pellets \\
\hline DM (\%) & $52.9 \pm 0.46$ & $95.3 \pm 1.13$ \\
Ash & $2.9 \pm 0.07$ & $10.4 \pm 0.15$ \\
Crude protein & $4.5 \pm 0.09$ & $17.9 \pm 0.2$ \\
Neutral detergent fiber & $33.4 \pm 0.32$ & $34.9 \pm 0.7$ \\
Acid detergent fiber & $22.9 \pm 0.23$ & $27.0 \pm 0.52$ \\
Condensed tannins ${ }^{2}$ & $23.1 \pm 0.36$ & $\mathrm{nd}^{3}$ \\
Organic matter digestibility $^{4}$ & $36.6 \pm 0.25$ & $70.3 \pm 0.68$ \\
Metabolizable energy $^{4}$ & $5.1 \pm 0.04$ & $9.5 \pm 0.1$ \\
\hline
\end{tabular}

${ }^{1}$ Means \pm SD.

${ }^{2}$ Condensed tannins expressed as g equivalent catechin per $100 \mathrm{~g} \mathrm{DM}$.

${ }^{3}$ nd indicates not detectable.

${ }^{4}$ Calculated from gas volume $(\mathrm{mL})$ produced at $24 \mathrm{~h}$ of incubation by the in vitro gas technique (Menke and Steingass 1988).

\section{Statistical Analysis}

Chemical composition and estimated in vitro OMD and ME of feed were subjected to analysis of variance using the PROC MIXED procedure of SAS (2004). Data on nutrient components of total intake and digestibility were combined across days for each treatment and analyzed by 1 -way analysis of variance (separately for animal species), with treatment included as the main effect. Simple effect treatment means for all response variables were compared using the least square means procedure, with the PDIFF (difference between $P$ values) option. Treatment and species effects on body weight differences were estimated with a fixed factor linear model. Polynomial contrasts were used to determine linear and quadratic responses to the PEG concentration. All procedures were conducted with SAS (2004), and effects significance was declared at $P<0.05$.

\section{RESULTS}

The chemical properties and estimated in vitro OMD and ME values of Arctostaphylos and alfalfa pellets are presented in Table 1. As expected, nutritional quality of Arctostaphylos was low as compared with alfalfa pellets. Condensed tannins concentration in Arctostaphylos was high, whereas no CT were detected in alfalfa pellets. Estimates of in vitro OMD and $\mathrm{ME}$ in Arctostaphylos were almost half of the estimates found for alfalfa pellets.

Tables 2 and 3 show the effect of PEG supplementation on nutrient intake (DM, OM, CP), ME intake, and in vivo digestibility of nutrients in sheep and goats fed Arctostaphylos. A curvilinear increase $(P<0.05)$ in DM intake and nutrient intake (as per $\mathrm{g} \cdot \mathrm{d}^{-1}$ and as per $\mathrm{kg} \mathrm{BW}{ }^{0.75}$ ) was observed in goats and sheep as concentration of PEG in drinking water increased. An exception to this trend was CP intake $\left(\mathrm{g} \cdot \mathrm{d}^{-1}\right)$ of Arctostaphylos by goats, which linearly increased $(P<0.001)$ as a response to PEG.

Digestibility coefficients for Arctostaphylos supplemented with alfalfa pellets without PEG were low as compared to those with PEG. Addition of PEG curvilinearly increased $(P<0.05)$ digestibility of DM, CP, and NDF and ADF, but quadratically increased $(P<0.05)$ OMD in goats and sheep. The highest 
Table 2. Daily mean intake and calculated metabolizable energy in goats and sheep fed Arctostaphylos canescens (ad libitum) and alfalfa pellets $(1.5 \%$ body weight $[B W])$ with and without addition of polyethylene glycol (PEG). ${ }^{1}$

\begin{tabular}{|c|c|c|c|c|c|c|c|}
\hline & \multicolumn{4}{|c|}{ PEG levels (\%BW) } & \multirow[b]{2}{*}{ SEM } & \multicolumn{2}{|c|}{ Contrasts } \\
\hline & 0 & 0.05 & 0.15 & 0.3 & & Linear & Quadratic \\
\hline \multicolumn{8}{|l|}{ Goats } \\
\hline$D M, g \cdot d^{-1}$ & $908.6 \mathrm{~b}$ & $943.2 \mathrm{~b}$ & $1107.7 \mathrm{a}$ & $1159.8 \mathrm{a}$ & 21.1 & $<0.001$ & 0.014 \\
\hline $\mathrm{DM}, \mathrm{g} \cdot \mathrm{kg}^{-1} \mathrm{BW}^{0.75}$ & $66.7 \mathrm{c}$ & $70.1 \mathrm{c}$ & $83.0 \mathrm{~b}$ & $87.6 \mathrm{a}$ & 1.27 & $<0.001$ & 0.001 \\
\hline $\mathrm{OM}, \mathrm{g} \cdot \mathrm{d}^{-1}$ & $848.6 \mathrm{~b}$ & $865.8 \mathrm{~b}$ & $993.7 \mathrm{a}$ & $997.1 \mathrm{a}$ & 19.5 & $<0.001$ & 0.011 \\
\hline $\mathrm{OM}, \mathrm{g} \cdot \mathrm{kg}^{-1} \mathrm{BW}^{0.75}$ & $62.3 \mathrm{~b}$ & $64.3 \mathrm{~b}$ & $74.5 \mathrm{a}$ & $75.4 \mathrm{a}$ & 1.23 & $<0.001$ & 0.002 \\
\hline$C P, g \cdot d^{-1}$ & $101.4 \mathrm{~b}$ & $102.7 \mathrm{~b}$ & $109.5 \mathrm{a}$ & $110.2 \mathrm{a}$ & 2.18 & 0.001 & 0.222 \\
\hline $\mathrm{CP}, \mathrm{g} \cdot \mathrm{kg}^{-1} \mathrm{BW}^{0.75}$ & $7.4 \mathrm{~b}$ & $7.6 \mathrm{~b}$ & $8.2 \mathrm{a}$ & $8.3 \mathrm{a}$ & 0.09 & $<0.001$ & 0.007 \\
\hline \multicolumn{8}{|l|}{ Calculated ME intake } \\
\hline$M J \cdot d^{-1}$ & $7.3 \mathrm{~b}$ & $7.6 \mathrm{~b}$ & $8.9 \mathrm{a}$ & $8.4 \mathrm{a}$ & 0.23 & $<0.001$ & 0.002 \\
\hline $\mathrm{MJ} \cdot \mathrm{kg}^{-1} \mathrm{BW}^{0.75}$ & $0.54 \mathrm{~b}$ & $0.57 \mathrm{~b}$ & $0.66 \mathrm{a}$ & $0.64 \mathrm{a}$ & 0.02 & $<0.001$ & 0.001 \\
\hline \multicolumn{8}{|l|}{ Sheep } \\
\hline$D M, g \cdot d^{-1}$ & $1294.1 \mathrm{C}$ & $1378.9 \mathrm{~b}$ & $1611.4 \mathrm{a}$ & $1574.7 \mathrm{a}$ & 25.2 & $<0.001$ & $<0.001$ \\
\hline $\mathrm{DM}, \mathrm{g} \cdot \mathrm{kg}^{-1} \mathrm{BW}^{0.75}$ & $64.1 \mathrm{c}$ & $68.7 \mathrm{~b}$ & $80.7 \mathrm{a}$ & $79.1 \mathrm{a}$ & 0.92 & $<0.001$ & $<0.001$ \\
\hline $\mathrm{OM}, \mathrm{g} \cdot \mathrm{d}^{-1}$ & $1195.1 \mathrm{c}$ & 1247.9 bc & $1415.9 \mathrm{a}$ & $1303.4 \mathrm{~b}$ & 24.2 & 0.001 & $<0.001$ \\
\hline $\mathrm{OM}, \mathrm{g} \cdot \mathrm{kg}^{-1} \mathrm{BW}^{0.75}$ & $59.2 d$ & 62.2 bc & $70.9 \mathrm{a}$ & $65.6 \mathrm{~b}$ & 0.93 & $<0.001$ & $<0.001$ \\
\hline$C P, g \cdot d^{-1}$ & $169.7 \mathrm{c}$ & 172.8 bc & $180.9 \mathrm{a}$ & $176.2 a b$ & 2.06 & 0.010 & 0.004 \\
\hline $\mathrm{CP}, \mathrm{g} \cdot \mathrm{kg}^{-1} \mathrm{BW}^{0.75}$ & $8.4 \mathrm{~d}$ & $8.6 \mathrm{c}$ & $9.1 \mathrm{a}$ & $8.9 \mathrm{~b}$ & 0.05 & $<0.001$ & $<0.001$ \\
\hline \multicolumn{8}{|l|}{ Calculated ME intake } \\
\hline$M J \cdot d^{-1}$ & $10.0 \mathrm{~b}$ & $10.8 \mathrm{~b}$ & $12.7 \mathrm{a}$ & $10.7 \mathrm{~b}$ & 0.30 & 0.046 & $<0.001$ \\
\hline $\mathrm{MJ} \cdot \mathrm{kg}^{-1} \mathrm{BW}^{0.75}$ & $0.50 \mathrm{c}$ & $0.54 \mathrm{~b}$ & $0.64 \mathrm{a}$ & $0.54 \mathrm{~b}$ & 0.013 & 0.009 & $<0.001$ \\
\hline
\end{tabular}

${ }^{1} \mathrm{DM}$ indicates dry matter; OM, organic matter; $\mathrm{CP}$, crude protein; and ME, metabolizable energy. Metabolizable energy concentrations were calculated using the NRC (1989) equation for digestible energy to metabolizable energy based on in vivo organic matter digestibility measurements. Means within rows that do not share a letter differ at $P<0.05$.

increase in Arctostaphylos intake by sheep and goats was obtained at $0.15 \%$ PEG as the highest level $(0.3 \%)$ did not show further increase in Arctostaphylos consumption.

Level of PEG supplementation affected $(P<0.001)$ the difference in body weight between beginning and end of the experimental period. Goats and sheep lost weight during the different experimental periods and treatments, except those supplemented with PEG at $0.15 \%$ of body weight (Table 4$)$.

\section{DISCUSSION}

Results on chemical composition and estimates of in vitro OMD and ME based on gas production obtained in this study support data previously reported about the low nutritional value of Arctostaphylos (Bissell and Weir 1957; Sidahmed et al. 1981a, 1981b; Narvaez et al. 2010) and high CT content (Kraus et al. 2003; Narvaez et al. 2010).

This study showed that despite supplementation of concentrate, Arctostaphylos CT may negatively affect the utilization of diet protein. Silanikove et al. (1997) reported that although high protein supplementation increased oak leaves and digestible protein intakes, a considerable portion of the supplemented protein was wasted because of interaction with tannins. In this study, administration of PEG to drinking water was effective to neutralize the deleterious effects of tannins in Arctostaphylos. Consistent with our results, other studies have reported the benefits from the use of PEG as a tanninneutralizing agent to improve the nutritive value of tanninifer- ous feeds (Silanikove et al. 1997; Silanikove et al. 2001; Ben Salem et al. 2005).

Administration of PEG resulted in a substantial increase in intake of Arctostaphylos by sheep and goats and improved ME intake and DM digestibility. PEG supplied at $0.15 \% \mathrm{BW}$ to sheep $\left(\operatorname{avg}=83.5 \mathrm{~g} \cdot \mathrm{d}^{-1}\right)$ and goats $\left(\operatorname{avg}=43.3 \mathrm{~g} \cdot \mathrm{d}^{-1}\right)$ was the optimal level to maximize deactivation of reactive CT from Arctostaphylos. Thus, this level of PEG in drinking water resulted in considerable increases in the intake of DM $(24.5 \%$ in goats and $25.9 \%$ in sheep), CP $(10.8 \%$ in goats and $8.3 \%$ in sheep), and $\mathrm{ME}(22.2 \%$ in goats and $28 \%$ in sheep) of Arctostaphylos per unit of metabolic weight. Optimum responses in DM intake have been obtained in sheep fed Acacia cyanophylla at $23 \mathrm{~g} \cdot \mathrm{d}^{-1}$ PEG in feed blocks (Ben Salem et al. 2000) and in goats fed leaves of Ceratonia siliqua and Quercus calliprinus at $10 \mathrm{~g} \cdot \mathrm{d}^{-1}$ PEG or Pistacia lentiscus at $20 \mathrm{~g} \cdot \mathrm{d}^{-1}$ PEG (Silanikove et al. 1996). Increased intake of tanniniferous plants with addition of PEG has been associated to increased rate and extend of DM digestion in the rumen (Waghorn et al. 1994).

It has been suggested that PEG effects on digestibility are greater than on voluntary intake, particularly with regard to protein (Decandia et al. 2000). The considerable impact of CT in our study was made evident by the low CP and fiber (NDF and ADF) digestibility of the diet in both animal species in the absence of PEG. It is assumed that reductions in CP and fiber digestibility are consequences of CT binding to dietary constituents or to bacteria, and to inhibition of microbial growth and microbial enzyme activity (Jones et al. 1994; 
Table 3. In vivo digestibility coefficients in goats and sheep fed Arctostaphylos canescens (ad libitum) and alfalfa pellets (1.5\% body weight [BW]) with and without addition of polyethylene glycol (PEG). ${ }^{1}$

\begin{tabular}{|c|c|c|c|c|c|c|c|}
\hline & \multicolumn{4}{|c|}{ PEG levels (\%BW) } & \multirow[b]{2}{*}{ SEM } & \multicolumn{2}{|c|}{ Contrasts } \\
\hline & 0 & 0.05 & 0.15 & 0.3 & & Linear & Quadratic \\
\hline \multicolumn{8}{|l|}{ Goats } \\
\hline Dry matter & $55.6 \mathrm{~b}$ & $57.4 \mathrm{ab}$ & $59.4 \mathrm{a}$ & $58.4 \mathrm{a}$ & 0.95 & 0.031 & 0.047 \\
\hline Organic matter & $56.3 \mathrm{a}$ & $57.3 \mathrm{a}$ & $58.2 \mathrm{a}$ & $55.2 \mathrm{a}$ & 0.99 & 0.311 & 0.05 \\
\hline Crude protein & $37.6 \mathrm{c}$ & $51.6 \mathrm{~b}$ & $65.6 \mathrm{a}$ & $68.2 \mathrm{a}$ & 1.45 & $<0.001$ & $<0.001$ \\
\hline Neutral detergent fiber & $4.8 \mathrm{c}$ & $12.6 \mathrm{~b}$ & $21.0 \mathrm{a}$ & $19.2 \mathrm{a}$ & 2.05 & $<0.001$ & 0.001 \\
\hline Acid detergent fiber & $-11.2 \mathrm{c}$ & $-2.9 b$ & $4.7 \mathrm{a}$ & $3.5 \mathrm{a}$ & 2.33 & $<0.001$ & 0.003 \\
\hline \multicolumn{8}{|l|}{ Sheep } \\
\hline Dry matter & $53.5 \mathrm{c}$ & $56.3 \mathrm{~b}$ & $59.7 \mathrm{a}$ & $58.1 \mathrm{ab}$ & 0.89 & 0.001 & 0.001 \\
\hline Organic matter & $54.5 \mathrm{bc}$ & $56.4 \mathrm{ab}$ & $58.9 \mathrm{a}$ & $53.3 \mathrm{c}$ & 0.93 & 0.233 & $<0.001$ \\
\hline Crude protein & $39.8 d$ & $55.3 \mathrm{c}$ & $64.3 \mathrm{~b}$ & $69.2 \mathrm{a}$ & 1.02 & $<0.001$ & $<0.001$ \\
\hline Neutral detergent fiber & $5.7 \mathrm{c}$ & $16.2 \mathrm{~b}$ & $28.5 \mathrm{a}$ & $31.7 \mathrm{a}$ & 1.64 & $<0.001$ & $<0.001$ \\
\hline Acid detergent fiber & $-6.7 d$ & $5.0 \mathrm{C}$ & $14.1 \mathrm{~b}$ & $20.4 \mathrm{a}$ & 1.89 & $<0.001$ & 0.001 \\
\hline
\end{tabular}

${ }^{1}$ Means within rows that do not share a letter differ at $P<0.05$.

McAllister et al. 1994). However, the inhibitory effect of CT depends not only on their concentration in the plant tissue, but also on their nature and chemical structure (Hagerman 1992; McAllister et al. 2005). Therefore, results from this study suggest that adverse effects of Arctostaphylos CT on nutrient intake and digestibility in sheep and goats are mainly due to their concentration and chemical structure, which had probably sufficient biological activity for complexing most of the alfalfa proteins. High CT concentration and capacity to precipitate protein (BSA) was reported by Narvaez et al. (2010) in three predominant Arctostaphylos species (Arctostaphylos canescens, Arctostaphylos glandulosa, and Arctostaphylos stanfordiana) from California chaparral.

In this study, PEG increased CP digestibility and fiber digestibility of the diet in goats and sheep, allowing a better utilization of Arctostaphylos and a greater efficacy of alfalfa supplementation. Silanikove et al. (1996) reported that PEG supplementation improved NDF digestibility of tannin-containing leaves fed to goats by decreasing the protein-tannin complex determined as NDF in feces.

The PEG-mediated differences in Arctostaphylos intake and digestibility by sheep and goats in this study suggest decreased biological activity of the Arctostaphylos CT. The tanninbinding activity of PEG decreased the number of reactive phenolic and hydroxyl groups in the CT, thereby reducing their capacity to bind carbohydrates and proteins. Higher intake of Arctostaphylos when PEG was administered in the drinking water also suggests improved palatability to sheep and goats by reducing tannin astringency in the mouth. Improvements in intake and digestibility when PEG was added to a tannincontaining diet have been previously reported (Leinmüller et al. 1991; Silanikove et al. 1997; Ben Salem et al. 2002; Ben Salem et al. 2005).

Low NDF digestibility and negative values of ADF digestibility found in this study may be attributed to the presence of tannin-protein complexes formed during passage through the digestive tract acting as artifacts in feces being included as overestimates of true-fecal fiber excreted (Ben Salem et al. 2000; Bhatta et al. 2002; Motubatse et al. 2008). In fact, NDF and ADF values in this study were determined without the addition of sodium sulfite, as suggested by Robbins et al. (1987) and Van Soest (1994) for tannin-containing forages to remove insoluble protein-tannin complexes. In consequence, tannins bound to the protein could appear as residues with values higher than expected.

Live weight decreased in goats and sheep in all treatments, except at the $0.15 \%$ PEG supplementation level. Higher body weight at $0.15 \%$ BW of PEG might be a result of the increased protein digestibility and intake in goats and sheep. In contrast, weight loss by sheep and goats as response to the higher PEG level may have been related to a protein-energy imbalance resulting from PEG effects on alfalfa protein release together with low energy content in the diet. Conversely, the lower level of PEG may have been insufficient to deactivate all the antinutritive effects of Arctostaphylos CT. Positive effects of PEG supplementation on body weight in sheep and goats have been previously reported (Silanikove et al. 1997; Bhatta et al. 2002). However, it is important to note that PEG alters osmotic

Table 4. Body weight $(\mathrm{BW})$ difference $(\mathrm{kg})$ and standard deviation of experimental animals. ${ }^{1}$

\begin{tabular}{lcccccc}
\hline & \multicolumn{5}{c}{ PEG levels $(\% \mathrm{BW})$} & \\
\cline { 2 - 5 } Species & 0 (control) & 0.05 & 0.15 & 0.3 & SEM & $P$ value \\
\hline Goat & $-0.20 \pm 0.30$ & $-0.23 \pm 0.30$ & $0.35 \pm 0.07$ & $-0.76 \pm 1.09$ & 0.256 & 0.012 \\
Sheep & $-0.11 \pm 0.38$ & $-0.23 \pm 0.32$ & $0.92 \pm 0.74$ & $-1.98 \pm 1.58$ & 0.356 & 0.001 \\
\hline
\end{tabular}

${ }^{1}$ PEG indicates polyethylene glycol. 
pressure in the rumen fluid by increasing the rate of fermentation and that water intake is the mechanism by which ruminant adjusts the rumen osmolality (Moujahed et al. 2000). In consequence, data on body weight change and average body mass gains in this study may reflect changes in rumen content as much as changes occurring in body tissues and therefore should be treated with caution. In addition, the animals were on a short-duration trial, and it may not be enough to reflect the level of performance the feed might support if fed for a long time.

\section{MANAGEMENT IMPLICATIONS}

The results from this study suggest that tannins present in Arctostaphylos affect considerably the utilization of the supplementary protein provided to goats and sheep. The administration of PEG to the drinking water of both sheep and goats is an effective way of neutralizing the deleterious effects of tannins in Arctostaphylos. Addition of PEG at $0.15 \%$ BW leads to a better utilization of nutrients from the tanninrich Arctostaphylos and enhances efficacy of alfalfa supplementation. This level of PEG allowed a balanced and a greater supply of energy and protein that resulted in increased intake and digestibility by sheep and goats. These findings have important management implications for use of PEG in applications of prescribed herbivory for vegetation management programs targeting Arctostaphylos-dominant sites. However, although at the $0.15 \%$ of PEG incorporation this practice was quite effective, PEG is relatively expensive, and the success of its adoption will depend on the cost-benefit ratio. An economic analysis (i.e., cost to return) associated with PEG supplementation for this study over the long term would be appropriate and should include 1) investments in prevention and control of fire and undesirable brush, where potential damage is far above the economic costs for animal feeding, 2) welfare and performance of animals used in vegetation management programs, and 3) economy in the use of highquality concentrate.

\section{ACKNOWLEDGMENTS}

We thank M. Dally for technical assistance and care of the animals and the Ruminant Nutrition Laboratory, Animal Science Department of the University of California at Davis for providing the facilities and laboratory equipment for the chemical analysis. We are grateful to Katherine Jakober and Toby Entz for their helpful comments on this manuscript.

\section{LITERATURE CITED}

Association of Official Analytical Chemists. 1990. Official methods of analysis. 15th ed. Arlington, VA, USA: Association of Official Analytical Chemists. 30 p.

Badran, A. M., and D. E. Jones. 1965. Polyethylene glycol-tannin interaction in extracting enzyme. Nature 206:622-623.

BarRy, T. N., AND W. C. McNabB. 1999. The implications of condensed tannins on the nutritive value of temperate forages fed to ruminants. British Journal of Nutrition 81:263-272.

Ben Salem, H., N. Atti, A. Priolo, and A. Nefzaoul. 2002. Polyethylene glycol in concentrate or feedblocks to deactivate condensed tannins in Acacia cyanophylla Lindl. foliage 1. Effects on intake, digestion and growth by Barbarine lambs. Animal Science 75:127-135.

Ben Salem, H., I. Ben Salem, and M. S. Ben Said. 2005. Effect of the level and frequency of PEG supply on intake, digestion, biochemical and clinical parameters by goats given kermes oak (Quercus coccifera L.)-based diets. Small Ruminant Research 56:127-137.

Ben Salem, H., A. Nefzaoui, L. Ben Salem, and J. L. Tisserand. 1999. Different means of administering polyethylene glycol to sheep: effect on the nutritive value of Acacia cyanophylla Lindl. foliage. Animal Science 68:809-818.

Ben Salem, H. A., L. Nefzadui, L. Ben Salem, and J. L. Tisserand. 2000. Deactivation of condensed tannins in Acacia cyanophylla Lindl. foliage by polyethylene glycol in feed blocks: effect on feed intake, diet digestibility, nitrogen balance, microbial synthesis and growth by sheep. Livestock Production Science 64:51-60.

Bhatta, R., A. K. Shinde, S. Vaithiyanathan, S. K. Sankhyan, and D. L. Verma. 2002. Effect of polyethylene glycol-6000 on nutrient intake, digestion and growth of kids browsing Prosopis cineraria. Animal Feed Science and Technology 101:45-54.

Bissell, H. D., AND W. C. WeiR. 1957. The digestibilities of interior live oak and chamise by deer and sheep. Journal of Animal Science 16:476-480.

BrenneCKe, L., AND W. PItTRoff. 2003. Hierarchical analysis of dietary preferences of sheep and goats during two seasons in California chaparral. Proceedings of the VII International Rangelands Congress; 26 July-1 August 2003; Durban, South Africa.

Broadhurst, R. B., AND W. T. Jones. 1978. Analysis of condensed tannins using acidified vanillin. Journal of the Science of Food and Agriculture 29:788-794

Decandia, M., M. Sitzia, A. Cabiddu, D. Kababya, and G. Molle. 2000. The use of polyethylene glycol to reduce the anti-nutritional effects of tannins in goats fed woody species. Small Ruminant Research 38:157-164.

Getachew, G., E. J. Depeters, P. H. Robinson, and J. E. Fadel. 2005. Use of an in vitro rumen gas production technique to evaluate microbial fermentation of ruminant feeds and its impact on fermentation products. Animal Feed Science and Technology 123-124:547-559.

Getachew, G., H. P. S. MakkaR, and K. Becker. 2002. Tropical browses: contents of phenolic compounds, in vitro gas production and stoichiometric relationship between short chain fatty acid and in vitro gas production. Journal of Agricultural Science 139:341-352.

Hagerman, A. E. 1992. Tannin-protein interactions. In: C. T. Ho, C. Y. Lee, and M. T. Huang [EDS.]. Phenolic compounds in food and their effects on health. I. Analysis, occurrence, and chemistry. Washington, DC, USA: American Chemical Society. p. 236-247.

HART, S. P. 2001. Recent perspectives in using goats for vegetation management in USA. Journal of Dairy Science 84:E170-E176.

Jones, G. A., T. A. McAllister, A. D. Muir, and K. J. Cheng. 1994. Effects of sanfoin (Onobrychis viciifolia Scop.) condensed tannins on growth and proteolysis by four strains of ruminal bacteria. Applied and Environmental Microbiology 60:1374-1378.

Khazaal, K. A., M. T. Dentinho, R. Ribeiro, and E. R. Orskov. 1993. A comparison of gas production during incubation with rumen contents in vitro and nylon bag degradability as predictors of the apparent digestibility in vivo and voluntary intake of hays. Animal Production 57:105-112.

Kraus, T. E. C., Z. Yu, C. M. Preston, R. A. Dahlgren, and R. J. Zasoski. 2003. Linking chemical reactivity and protein precipitation to structural characteristics of foliar tannins. Journal of Chemical Ecology 29:703-730.

Kumar, R., and S. Vaithiyanathan. 1990. Occurrence, nutritional significance, and effect on animal productivity of tannins in tree leaves. Animal Feed Science and Technology 30:21-38.

Leinmüller, E., H. Steingass, and K. H. Menke. 1991. Tannins in ruminant feedstuffs. Animal Research and Development 33:9-62.

MaKKaR, H. P. S. 2003. Effects and fate of tannins in ruminant animals, adaptation to tannins, and strategies to overcome detrimental effects of feeding tanninrich feeds. Small Ruminant Research 49:241-256.

McAllister, T. A., H. D. BAe, G. A. Jones, and K. J. Cheng. 1994. Microbial attachment and feed digestion in the rumen. Journal of Animal Science 72:3004-3018. 
McAllister, T. A., T. F. Martinez, H. D. Bae, A. D. Muir, L. J. Yanke, and G. A. Jones. 2005. Characterization of condensed tannins purified from legume forages: chromophore production, protein precipitation, and inhibitory effects on cellulose digestion. Journal of Chemical Ecology 31:2049-2068.

Menke, K. H., and H. Steingass. 1988. Estimation of the energetic feed value obtained from chemical analysis and in vitro gas production using rumen fluid. Animal Research and Development 28:7-55.

Motubatse, M. R., J. W. NG'ambi, D. Norris, and M. M. Malatje. 2008. Effect of polyethylene glycol 4000 supplementation on the performance of indigenous Pedi goats fed different levels of Acacia nilotica leaf meal and ad libitum Buffalo grass hay. Tropical Animal Health and Production 40:229-238.

Moujahed, N., C. Kayouli, A. Thewis, Y. Beckers, and S. Rezgul. 2000. Effects of multinutrient blocks and polyethylene glycol 4000 supplies on intake and digestion by sheep fed Acacia cyanophylla Lindl. foliage-based diets. Animal Feed Science and Technology 88:219-238.

Narvaez, N., A. Brosh, and W. Pittroff. 2010. Seasonal dynamics of the nutritional properties of California chaparral species. Animal Feed Science and Technology 158:44-56.

NASTIS, A. S., AND J. C. MaleCheK. 1988. Estimating digestibility of oak browse diets for goats by in vitro techniques. Journal of Range Management 41:255-258.

[NRC] National Research Council. 1989. Nutrient requirements of dairy cattle. Washington, DC, USA: National Academic Press. $157 \mathrm{p}$.

Robbins, C. T., S. Mole, A. E. Hagerman, and T. A. Hanley. 1987. Role of tannins in defending plants against ruminants reduction in dry matter digestion. Ecology 68:1606-1615.

Rundel, P. W., and D. J. Parsons. 1980. Nutrients changes in two chaparral shrubs along a fire-induced age gradient. American Journal of Botany 67:51-58.

Rundel, P. W., D. J. Parsons, and G. A. Baker. 1980. The role of shrub structure and chemistry in the flammability of chaparral shrubs. In: Proceedings of the 2nd Conference on Scientific Research in National Parks. Washington, DC, USA: US Department of the Interior, National Park Service. p. 248-260.
Sampson, A. W., and B. S. Jespersen. 1963. California range brushlands and browse plants. Oakland, CA, USA: Agriculture and Natural Resources. 163 p.

SAS. 2004. SAS/STAT User's Guide. Version 9.1. Cary, NC, USA: SAS Institute Inc.

Sidahmed, A. E., J. G. Morris, L. J. Koong, and S. R. Radosevich. 1981a. Contribution of mixtures of three chaparral shrubs to the protein and energy requirements of Spanish goats. Journal of Animal Science 53:1391-1400.

Sidahmed, A. E., J. G. Morris, and S. R. Radosevich. 1981b. Summer diet of Spanish goats grazing chaparral. Journal of Range Management 34:33-35.

Silanikove, N., N. Gilboa, I. NiR, A. Perevolotsky, and Z. Nitsan. 1996. Effect of a daily supplementation of polyethylene glycol on intake and digestion of tannin-containing leaves (Quercus calliprinos, Pistacia lentiscus, and Ceratonia siliqua) by goats. Journal of Agricultural and Food Chemistry 44:199-205.

Silanikove, N., N. GilboA, and Z. Nitsan. 1997. Interactions among tannins, supplementation and polyethylene glycol in goats given oak leaves: effects on digestion and food intake. Animal Science 64:479-483.

Silanikove, N., A. Perevolotsky, and F. D. Provenza. 2001. Use of tannin-binding chemicals to assay for tannins and their negative postingestive effects in ruminants. Animal Feed Science and Technology 91:69-81.

VAn SoEST, P. J. 1994. Nutritional ecology of the ruminant. Ithaca, NY, USA: Cornell University Press. 476 p.

Van Soest, P. J., J. B. Robertson, and B. A. Lewis. 1991. Methods for dietary fiber, neutral detergent fiber, and non-starch polysacharides in relation to animal nutrition. Journal of Dairy Science 74:3583-3597.

Van Sumere, C. F., J. Albrecht, A. Dedonder, H. De Pooter, and I. Pé. 1975. Plant proteins and phenolics. In: J. Harborne and C. F. Van Sumere [EDS.]. The chemistry and biochemistry of plant proteins. New York, NY, USA: Academic Press. p. 211-264.

Waghorn, G. C., I. D. Shelton, and W. C. McNabb. 1994. Effects of condensed tannins in Lotus pedunculatus on its nutritive value for sheep: 1. Nonnitrogenous aspects. Journal of Agricultural Science 123:99-107. 